\title{
KUALITAS AIR DAN KELANGSUNGAN HIDUP UDANG KETAK (Harpiosquilla raphidea) YANG DIPELIHARA PADA WADAH MENGGUNAKAN SUBSTRAT DAN TANPA SUBSTRAT
}

\author{
M. Yusuf Arifin ${ }^{1 *}$, M. Sugihartono ${ }^{1}$ \\ ${ }^{1}$ Program Studi Budidaya Perairan, Fakultas Pertanian Universitas Batanghari \\ J1. Slamet Riyadi, Broni Jambi. 36122. Telp. +62074160103 \\ email korespondensi : yusuf_arifin88@yahoo.com \\ email : $\underline{m}$ shartono@yahoo.com
}

\begin{abstract}
The high mortality of shrimp ketak (Harpiosquilla raphidea) in a temporary shelter is causing the low number of stays to be shrimp exports, while demand for the export market demand for the availability of an individual shrimp (Harpiosquilla raphidea) in living conditions. The main factors affecting the lingkugan factor is primarily the quality of the water. Therefore it needs an appropriate technology in order to maintain the water quality conditions of the media during the quarantine process prior to the shrimp for sale. This research was conducted for 30 days with the treatment that is the giving of the substrate on the bottom of the container in the form of active charcoal, and without granting the substrate (control). The observed water quality parameters i.e., $\mathrm{NH} 3, \mathrm{pH}$, temperature, DO, Nitrite and nitrate. Water quality parameter measurements performed on the 0,10,20 and 30 days, while the Survival rate figure is calculated at the end of the study. The results showed that the water quality conditions and the survival rate is best found on the substrate active charcoal granting preferential treatment. Conclusion of this research is the awarding of the substrate to the active charcoal on the bottom of the container maintenance shrimp ketak (Harpiosquilla raphidea) was able to maintain water quality and produce the survival rate of $89 \%$.
\end{abstract}

Keywords:, prawns, Harpiosquilla, substrate, water quality, SR.

\begin{abstract}
Abstrak
Tingginya kematian udang ketak (Harpiosquilla raphidea) di tempat penampungan sementara menyebabkan rendahnya jumlah udang ketak yang akan di ekspor, sementara permintaan pasar ekspor menuntut untuk tersedianya udang ketak (Harpiosquilla raphidea) dalam kondisi hidup. Faktor utama yang mempengaruhi adalah factor lingkugan terutama kualitas air. Oleh karena itu dibutuhkan teknologi yang tepat guna mempertahankan kondisi kualitas air media selama berlangsungnya proses karantina sebelum udang dijual. Penelitian ini dilakukan selama 30 hari dengan perlakuan yaitu pemberian substrat pada bagian dasar wadah pemeliharan berupa arang aktif, dan tanpa pemberian substrat (kontrol). Parameter kualitas air yang diamati yaitu $\mathrm{NH}_{3}$, $\mathrm{pH}$, suhu, DO, Nitrit dan Nitrat. Pengukuran parameter kualitas air dilakukan pada hari ke-0, 10, 20 dan hari ke-30, sedangkan angka Survival rate dihitung pada akhir penelitian. Hasil penelitian menunjukkan bahwa kondisi kualitas air dan tingkat kelangsungan hidup terbaik terdapat pada perlakuan pemberian substrat arang aktif. Kesimpulan dari penelitian ini adalah pemberian substrat arang aktif pada bagian dasar wadah pemeliharaan udang ketak (Harpiosquilla raphidea) mampu mempertahankan kualitas air dan menghasilkan tingkat kelangsungan hidup sebesar $89 \%$.
\end{abstract}

Kata kunci:, Udang, Harpiosquilla,, Substrat, Kualitas air, SR 


\section{PENDAHULUAN}

Udang Ketak (Harpiosquilla raphidea) merupakan salah satu produk unggulan dari daerah Kabupaten Tanjung Jabung Timur dan Kabupaten Tanjung Jabung Barat Propinsi Jambi yang di ekspor ke beberapa negara seperti Taiwan, Jepang, dan China. Udang ketak memiliki nilai ekonomis cukup tinggi dengan harga pasar ekspor untuk ukuran kelas A $(>25 \mathrm{~cm})$ dan kelas B $(20-25 \mathrm{~cm})$ berkisar antara Rp.20.000 sampai Rp.40.000 per-ekor dengan kondisi udang dalam keadaan hidup.

Sebelum dikirim ke manca negara, udang ketak terlebih dahulu dikumpulkan di tempat-tempat penampungan milik pedagang pengumpul. Permintaan pasar ekspor yang menuntut kondisi udang harus tetap hidup sampai ke tempat tujuan membuat para eksportir harus lebih fokus melakukan pemeliharaan hingga jumlah udang yang terkumpul telah mencukupi target penjualan. Pada masa pemeliharaan tersebut udang ketak sering mengalami kematian akibat stres yang terjadi karena adanya perubahan kondisi lingkungan terutama perubahan kualitas air.

Penggunan air secara berulang-ulang (system resirkulasi) selama proses budidaya ikan menyebabkan terjadinya penumpukan bahan organik seperti amonia (NH3), Nitrit $\left(\mathrm{NO}_{2}\right)$ dan nitrat $\left(\mathrm{NO}_{3}\right)$. Keberadaan bakteri nitrifikasi memegang peranan penting dalam proses oksidasi ammonia menjadi nitrit $\left(\mathrm{NO}_{2}\right)$ yang dilakukan oleh bakteri Nitrosomonas dan oksidasi nitrit menjadi nitrat $\left(\mathrm{NO}_{3}\right)$ dilakukan oleh bakteri Nitrobacter (Effendi, 2000). Proses nitrifikasi akan berlangsung baik karena adanya bakteri yang hidup menempel pada substrat yang berada didalam air. Substrat mutlak diperlukan sebagai tempat menempel bakteri sehingga bisa memanfaatkan ammonia dan nitrit sebagai bahan makanannya yang menghasilkan produk akhir berupa nitrat (Djokosetiyanto et.al, 2006). Karbon aktif merupakan salah satu bahan substrat yang sering digunakan untuk menetralisir amonia pada unit budidaya ikan secara intensif dengan system resirkulasi air. Penggunaan karbon aktif didalam air mampu mengadsorpsi sejumlah amonia dalam waktu tertentu (Supriyono, et.al, 2007).

Berdasarkan uraian diatas, perlu kiranya dilakukan kajian terhadap kondisi kualitas air terutama kadar NH3 terlarut didalam air selama pemeliharaan udang ketak baik itu pada wadah yang menggunakan substrat karbon aktif maupun air pada wadah tanpa menggunakan substrat.

\section{METODOLOGI PENELITIAN}

Penelitian dilakukan selama 30 hari pada unit budidaya ikan dengan kondisi ruangan tertutup (Hatcreey). Perlakuan yang akan diuji yaitu pemeliharaan udang ketak didalam wadah yang diberi substrat berupa arang aktif, selanjutnya disebut sebagai P1, dan pemeliharaan udang ketak didalam wadah tanpa menggunakan substrat, selanjutnya disebut sebagai $\mathrm{P} 2$

Wadah yang digunakan berupa bak terpal dengan ukuran $150 \mathrm{~cm}$ x $50 \mathrm{~cm}$ x 40 $\mathrm{cm}$ yang dilengkapi dengan system resirkulasi air. Wadah yang digunakan untuk masing-masing perlakuan adalah 3 unit, sehingga total wadah yang dibutuhkan sebanyak 6 unit. Pemberian arang aktif dilakukan dengan cara ditebarkan pada bagian dasar bak pemeliharaan dengan ketebalan $5 \mathrm{~cm}$. Arang aktif yang digunakan terbuat dari tempurung kelapa yang telah melalui proses pengarangan pada suhu $500{ }^{\circ} \mathrm{C}-700{ }^{\circ} \mathrm{C}$ dan kemudian diaktivasi menggunakan larutan $\mathrm{NaOH}$ (Riwayati, 2005).

Air yang digunakan adalah air laut dengan salinitas 28 ppt. Sebelum digunakan air laut tersebut terlebih dahulu selanjutnya diaerasi dan difiltrasi selama 24 jam. 
Pengisian air kedalam wadah perlakuan adalah setinggi $30 \mathrm{~cm}$ dengan kondisi air selalu mengalir terus menerus menggunakan system resirkulasi.

Biota uji yang digunakan adalah udang ketak (Harpiosquilla raphidea) berukuran panjang tubuh 15-20 cm (Kelas B) yang diperoleh dari hasil tangkapan nelayan di Kabupaten Tanjung Jabung Timur. Setiap wadah perlakuan diisi udang ketak sebanyak 10 ekor, sehingga total udang ketak yang digunakan adalah sebanyak 60 ekor. Selama pemeliharaan udang ketak diberi pakan berupa ikan rucah dengan frekuensi pemberian pakan sebanyak $3 \mathrm{kali} / \mathrm{hari}$.

Parameter yang diamati adalah tngkat kelangsungan hidup dan kondisi kualitas air dengan parameter yang diukur yaitu kadar amonia, nitrit, nitrat, suhu, $\mathrm{pH}$, Disolved Oksigen (DO). Pengukuran parameter uji dilakukan pada hari ke-0, hari ke-10, hari ke20, dan hari ke-30. Data yang diperoleh dianalisis secara statistik dengan menggunakan uji-t.

\section{HASIL DAN PEMBAHASAN}

Hasil analisa laboratorium terhadap beberapa parameter kualitas air selama pemeliharaan udang ketak dengan perlakuan pemberian substrat arang aktif dan wadah tanpa pemberian substrat disajikan dalam Tabel 1.

Tabel 1. Rata-rata nilai parameter kualitas air pada wadah yang diberi substrat arang aktif dan pada wadah tanpa pemberian substrat dihari ke-0, hari ke-1, hari ke20, dan hari ke-30.

\begin{tabular}{lrrrrrrrr}
\hline \multirow{2}{*}{ PARMETER } & \multicolumn{2}{c}{ Hari ke-0 } & \multicolumn{2}{c}{ Hari ke-10 } & \multicolumn{2}{c}{ Hari ke-20 } & \multicolumn{2}{c}{ Hari ke-30 } \\
\cline { 2 - 9 } & \multicolumn{1}{c}{ P1 } & \multicolumn{1}{c}{ P2 } & \multicolumn{1}{c}{ P1 } & \multicolumn{1}{c}{ P2 } & \multicolumn{1}{c}{ P1 } & \multicolumn{1}{c}{ P2 } & \multicolumn{1}{c}{ P1 } & \multicolumn{1}{c}{ P2 } \\
\hline Amonia $(\mathrm{mg} / \mathrm{L})$ & 0.027 & 0.027 & 0.033 & 0.053 & 0.051 & 0.13 & 0.043 & 0.16 \\
Nitrit $(\mathrm{mg} / \mathrm{L})$ & 0.03 & 0.03 & 0.04 & 0.09 & 0.07 & 0.33 & 0.05 & 0.63 \\
Nitrat $(\mathrm{mg} / \mathrm{L})$ & 0.05 & 0.05 & 0.09 & 0.06 & 0.13 & 0.07 & 0.16 & 0.09 \\
Suhu $\left({ }^{\circ} \mathrm{C}\right)$ & 28 & 28 & 29.3 & 29.3 & 29 & 29 & 29 & 29 \\
DO $(\mathrm{mg} / \mathrm{L})$ & 5 & 5 & 5.33 & 5.35 & 5.36 & 5.36 & 5.3 & 5.31 \\
pH & 6.7 & 6.7 & 6.54 & 6.55 & 6.65 & 6.55 & 6.64 & 6.63 \\
\hline
\end{tabular}

Berdasarkan data pada Tabel 1 menunjukkan bahwa beberapa parameter masih berada dalam kisaran optimum yaitu parameter suhu yang berkisar antara $28-29,3^{\circ} \mathrm{C}$, nilai DO berkisar antara $5-5,36 \mathrm{mg} / \mathrm{L}$, nilai $\mathrm{pH}$ antara $6,55-6,7$, dan Nitrat berkisar antara $0,05-0,16 \mathrm{mg} / \mathrm{L}$. Namun untuk nilai amonia dan Nitrit cenderung melampaui batas optimum untuk budidaya ikan terutama pada hari ke 20 dan hari ke 30 .

Hasil analisis menggunakan uji $\mathrm{t}$ untuk parameter amonia dan nitrit menunjukkan perbedaan yang signifikan antara perlakuan P1 dengan perlakuan P2. Trend kadar amonia dan nitrit untuk kedua perlakuan disajikan dalam bentuk grafik pada Gambar 1. 
Jurnal Akuakultur Sungai dan Danau Vol. 2 No. 1 Tahun 2017 Hal. 18 - 24

ISSN Online 2503-4766

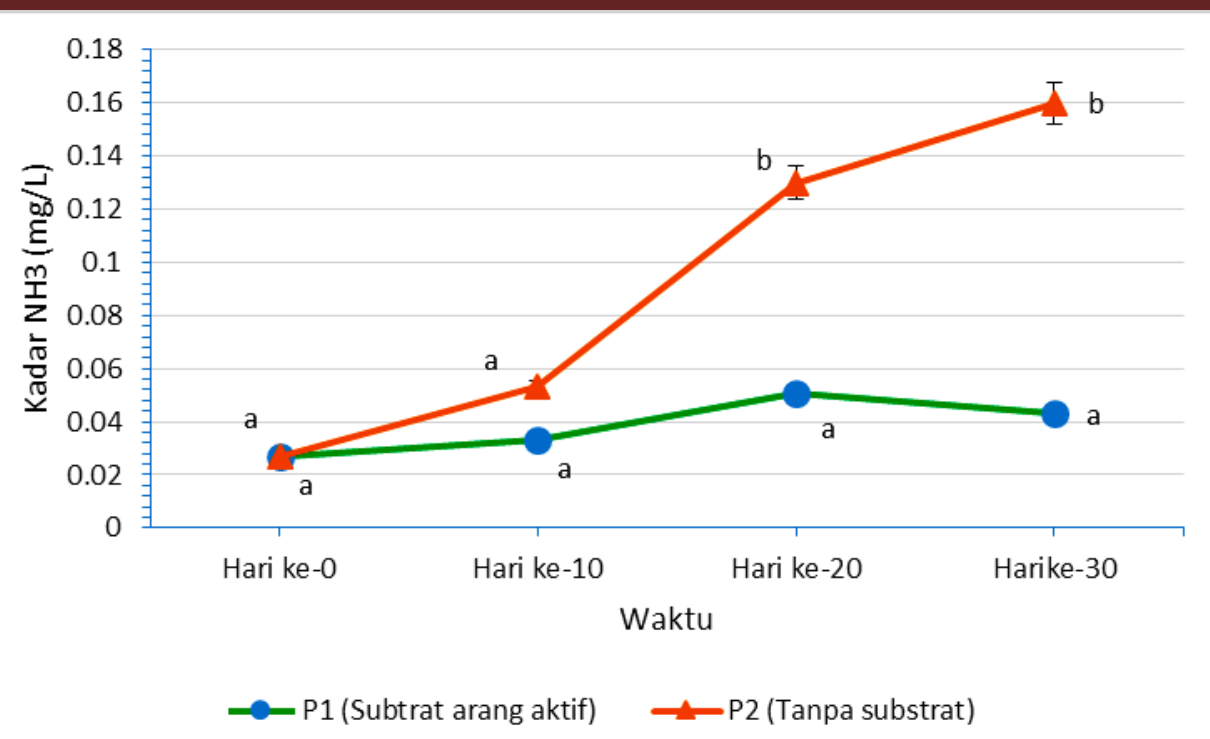

Gambar 1. Kadar amonia $\left(\mathrm{NH}_{3}\right)$ pada wadah yang diberi substrat arang aktif dan pada wadah tanpa pemberian substrat dihari ke-0, hari ke-1, hari ke-20, dan hari ke-30.

Grafik pada Gambar 1 menunjukkan adanya peningkatan kadar amonia $\left(\mathrm{NH}_{3}\right)$ pada perlakuan P2 yang cenderung lebih tinggi dibanding perlakuan P1. Kadar $\mathrm{NH}_{3}$ terlarut dalam air pada perlakuan $\mathrm{P} 1$ yaitu sebesar $0,027 \mathrm{mg} / \mathrm{L}$ dihari ke-0 meningkat menjadi $0,33 \mathrm{mg} / \mathrm{L}$ dihari ke-10, selanjutnya $0,051 \mathrm{mg} / \mathrm{L}$ dihari ke-20, dan pada hari ke30 terjadi penurunan yaitu sebesar $0,043 \mathrm{mg} / \mathrm{L}$. Sedangkan kadar NH3 pada perlakuan P2 yaitu sebesar $0,027 \mathrm{mg} / \mathrm{L}$ dihari ke-0 meningkat menjadi $0,053 \mathrm{mg} / \mathrm{L}$ dihari ke- 10 , kemudian meningkat lagi di hari ke-20 sebesar $0,13 \mathrm{mg} / \mathrm{L}$, selanjutnya dihari ke-30 masih terjadi peningkatan yaitu $0,16 \mathrm{mg} / \mathrm{L}$.

Hasil analisis uji-t menunjukkan adanya perbedaan signifikan terhadap kadar $\mathrm{NH}_{3}$ yang terjadi pada hari ke-20 dan hari ke-30, yaitu kadar $\mathrm{NH} 3$ pada perlakuan $\mathrm{P} 2$ cenderung lebih tinggi dibanding perlakuan $\mathrm{P} 1$. Tingginya kadar $\mathrm{NH}_{3}$ pada perlakuan $\mathrm{P} 2$ terjadi akibat adanya penumpukan bahan organik yang dihasilkan oleh adanya buangan metabolit udang ketak dan sisa pakan ikan rucah yang tidak termakan oleh udang. Menurut Silaban et al. (2012), konsentrasi amonia selama masa pemeliharaan ikan akan mengalami peningkatan seiring dengan bertambahnya waktu pemeliharaan, akibat adanya limbah organik yang semakin meningkat, baik dari buangan metabolit, feses ikan dan sisa pakan yang terakumulasi di perairan.

Trend kadar $\mathrm{NH}_{3}$ yang terjadi pada perlakuan P1 (Gambar 1) memang terlihat adanya peningkatan, namun cenderung lebih rendah dari perlakuan P2. Hal tersebut terjadi karena keberadaan arang aktif didasar wadah pemeliharaan mampu menyerap atau mengikat NH3 yang ada diperairan. Untuk menetralisir amonia dapat dilakukan dengan menggunakan karbon aktif yang mampu mengadsorpsi sejumlah amonia dalam waktu tertentu (Supriyono, et.al, 2007).

Selain itu keberadaan arang aktif pada wadah perlakuan memberikan peluang sebagai tempat menempelnya bakteri nitrifikasi yang berperan dalam proses perombakan amonia menjadi nitrit dan mempercepat perombakan nitrit menjadi nitrat yang cenderung tidak membahayakan kehidupan biota air. Hasil penelitian ini 
menunjukkan bahwa keberadaan arang aktif didalam wadah pemeliharaan udang ketak mampu mempercepat proses perombakan amonia menjadi nitrat yang terbukti dengan kadar nitrit yang cenderung lebih rendah pada perlakuan P1 dibanding perlakuan P2. Trend kadar nitrit didalam wadah pemeliharaan disajikan dalam bentuk grafik pada Gambar 2.

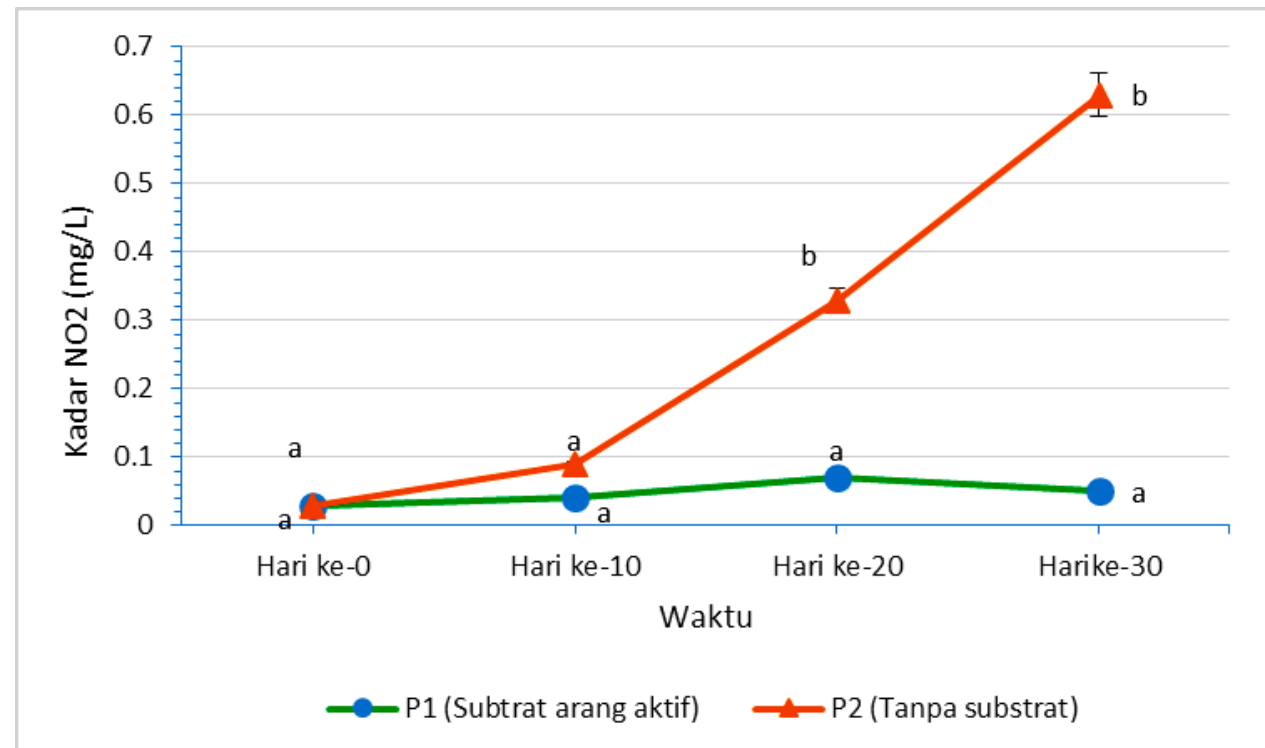

Gambar 2. Kadar nitrit $\left(\mathrm{NO}_{2}\right)$ pada wadah yang diberi substrat arang aktif dan pada wadah tanpa pemberian substrat dihari ke-0, hari ke-1, hari ke-20, dan hari ke-30

Trend kadar nitrit pada grafik (Gambar 2) menunjukkan perbedaan signifikan pada hari ke 20 dan hari ke 30. Pada perlakuan P2 kadar nitrit cenderung terjadi peningkatan dari awal hingga akhir pemeliharaan udang ketak, sedangkan kadar nitrit pada perlakuan P1 yang menggunakan substrata rang aktif cenderung terjadi peningkatan yang jauh lebih rendah dari perlakuan $\mathrm{P} 2$, bahkan pada hari ke 30 terjadi penurunan kadar nitrit dari $0,07 \mathrm{mg} / \mathrm{L}$ dihari ke 20 turun menjadi $0,05 \mathrm{mg} / \mathrm{L}$ dihari ke 30 .

Kondisi tersebut membuktikan bahwa keberadaan bakteri yang menempel pada arang aktif didalam wadah pemeliharaan mampu mempercepat proses perombakan nitrit menjadi nitrat yang merupakan produk akhir dari proses perombakan amonia. Keberadaan bakteri nitrifikasi memegang peranan penting dalam proses oksidasi ammonia menjadi nitrit $\left(\mathrm{NO}_{2}\right)$ yang dilakukan oleh bakteri Nitrosomonas dan oksidasi nitrit menjadi nitrat $\left(\mathrm{NO}_{3}\right)$ dilakukan oleh bakteri Nitrobacter (Effendi, 2000). Lebih lanjut menurut Djokosetiyanto, et.al, (2006), proses nitrifikasi berjalan dengan baik karena adanya bakteri yang hidup menempel pada substrat filter biologis. Substrat mutlak diperlukan sebagai tempat penempel bakteri sehingga bisa memanfaatkan ammonia dan nitrit sebagai bahan makanannya yang menghasilkan produk akhir berupa nitrat.

Tingginya kadar amonia dan nitrit didalam wadah pemeliharaan akan berdampak terhadap tingkat kelangsungan hidup biota air. Tingkat kelangsungan hidup udang ketak selama penelitian disajikan dalam bentuk grafik pada Gambar 3. 


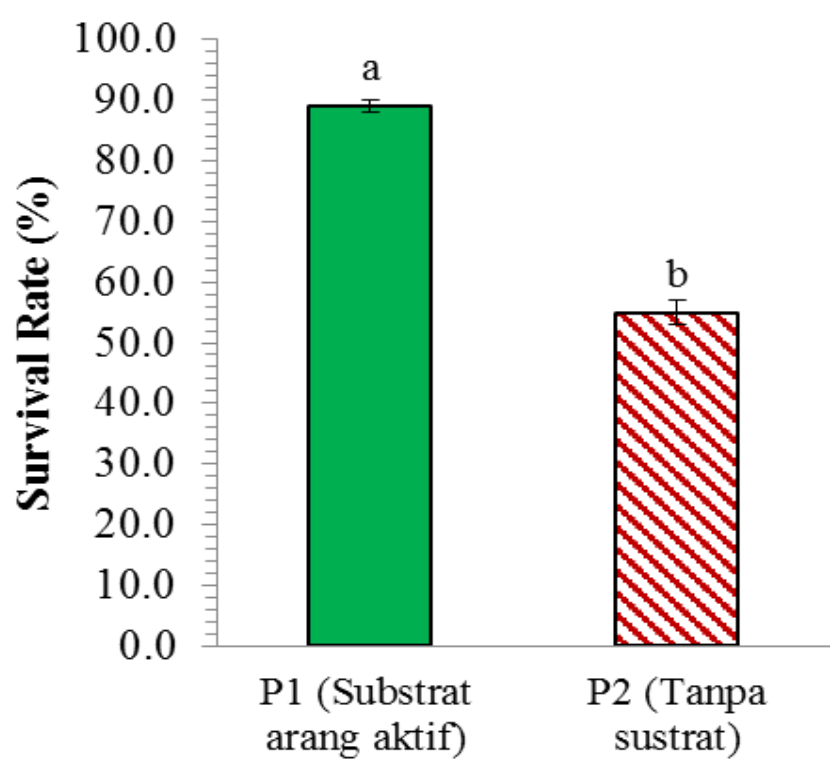

Gambar 3. Tingkat kelangsungan hidup (Survival Rate) udang ketak (Harpiosquilla raphidea) yang dipelihara dalam wadah menggunakan substrat arang aktif dan wadah tanpa substrat.

Hasil analisis uji t dan grafik pada Gambar 3 menunjukkan bahwa pemeliharaan udang ketak dalam wadah menggunakan substrat arang aktif dan wadah tanpa substrat menghasilkan perbedaan signifikan terhadap tingkat kelangsungan hidup udang ketak (Harpiosquilla raphidea). Penggunaan substrat arang aktif pada perlakuan P1 menghasilkan tingkat kelangsungan hidup sebesar 89\%, sedangkan pemeliharaan udang ketak dalam wadah tanpa substrat menghasilkan tingkat kelangsungan hidup yang lebih rendah yaitu sebesar $55 \%$.

Tingginya tingkat kelangsungan hidup udang ketak pada perlakuan P1 disebabkan oleh kondisi kualitas air terutama kandungan amonia dan nitrit yang cenderung lebih rendah dibanding perlakuan P2. Sedangkan rendahnya tingkat kelangsungan hidup udang ketak pada perlakuan P2 terjadi akibat tingginya kandungan amonia dan nitrit didalam wadah pemeliharaan. Ikan tidak dapat mentoleransi konsentrasi amonia yang terlalu tinggi karena dapat mengganggu proses pengikatan oksigen oleh darah dan pada akhirnya dapat mengakibatkan kematian (Yudha, 2009). Lebih lanjut menurut Irmanto dan Suyata (2009), Efek toksik yang ditimbulkan oleh nitrit adalah methemoglobin, yaitu terhambatnya proses pengangkutan oksigen di dalam aliran darah sehingga seluruh jaringan tubuh akan kekurangan oksigen yang akhirnya dapat menyebabkan kematian.

\section{KESIMPULAN DAN SARAN Kesimpulan}

Penggunaan substrat arang aktif didalam wadah pemeliharaan udang ketak mampu mempertahankan kondisi kualitas air terutama dalam hal penyerapan senyawa amonia $\left(\mathrm{NH}_{3}\right)$ dan nitrit $\left(\mathrm{NO}_{2}\right)$ yang dapat menghasilkan tingkat kelangsungan hidup sebesar $89 \%$. 
Penggunaan substrat dalam wadah pemeliharaan udang ketak dalam penelitian ini dianggap cukup efektif, sehingga biota ini sangat berpotensi untuk dibudidayakan. Oleh karena itu disarankan untuk melakukan penelitian lanjutan tentang perbedaan jumlah substrat arang aktif yang digunakan selama proses pemeliharaan udang ketak.

\section{DAFTAR PUSTAKA}

D. Djokosetiyanto, A. Sunarma dan Widanarni (2006), Perubahan Ammonia (NH3-N), Nitrit $\left(\mathrm{NO}_{2}-\mathrm{N}\right)$ dan Nitrat (NO3-N) Pada Media Pemeliharaan Ikan Nila Merah (Oreochromis sp.) Di Dalam Sistem Resirkulasi, Jurnal Akuakultur Indonesia, 5(1): 13-20 (2006)

E. Supriyono, A. Supendi dan K. Nirmala, 2007. Pemanfaatan Zeolit Dan Karbon Aktif Pada Sistem Pengepakan Ikan Corydoras (Corydoras aenus). Jurnal Akuakultur Indonesia, 6(2): 135-145 (2007)

Effendi.H,(2000). Telaahan Kualitas Air Bagi Pengelolaan Sumberdaya dan Lingkungan Perairan. Jurusan Manajemen Sumberdaya Perairan. Fakultas Perikanan dan Ilmu Kelautan. IPB. Bogor

Irmanto dan Suyata (2009). Penurunan Kadar Amonia, Nitrit, Dan Nitrat Limbah Cair Industri Tahu Menggunakan Arang Aktif Dari Ampas Kopi. Jurnal Molekul, Vo1. 4. No. 2. November, 2009 : 105 - 114

Silaban T.F, Santoso L, Suparmono (2012). Penambahan Zeolit Dalam Peningkatan Kinerja Filter Air Untuk Menurunkan Konsentrasi Amonia Pada Pemeliharaan Ikan Mas (Cyprinus Carpio). E-Jurnal Rekayasa Dan Teknologi Budidaya Perairan Volume I No 1 Oktober 2012, ISSN: 2302-3600

Yudha, P. A. 2009. Efektifitas penambahan zeolit terhadap kinerja filter air dalam sistem resirkulasi pada pemeliharan ikan arwana Sceleropages formosus di akuarium. Skripsi. Fakultas Perikanan dan Ilmu Kelautan. Institut Pertanian Bogor. 